\title{
Revival of inner-city retail areas: The potential role of property owners
}

Received: 29 April 2004

\section{Clifford Guy}

is a professor in the School of City and Regional Planning at Cardiff University. He has researched and taught retail planning issues for many years and is the author of The Retail Development Process (Routledge, 1994).

\begin{abstract}
Little is known about the ownership structures and attitudes of property owners in non-central retail and business areas of inner cities in the UK. This paper reports the findings of a survey carried out in Cardiff which attempted to investigate these structures and attitudes. It is found that ownership is fragmented across a wide variety of local individuals and companies, and that attitudes range from apparently complete unconcern over the area's problems to a deep concern for the future.
\end{abstract}

\section{Keywords:}

retailers, property owners, inner city

\section{INTRODUCTION}

This paper considers a previously neglected theme in the analysis of inner urban retail and business performance. It examines the roles - actual and potential - of property owners in the process of rejuvenating inner urban business areas which have fallen into decline.

The focus is on retail and business areas which lie outside town and city centres, but within the pre-1914 urban fabric. Many of these areas were important commercial and social hubs of the inner city, typically developed in 'ribbon' format along major radial routes. In recent years they have fallen into decline, however, due both to population losses and to competition from more modern city-centre and out-of-centre retailing. ${ }^{1}$

In a previous paper ${ }^{2}$ the problems facing Clifton Street - a

Clifford Guy

School of City and Regional Planning Cardiff University

Glamorgan Building King Edward VII Avenue Cardiff CF10 3WA, UK Tel: +1 (o) 2920875798 Fax: +1 (o) 2920874845 E-mail: guy@cardiff.ac.uk typical inner urban business area of around 100 retail and service premises in Cardiff - were described, drawing particularly on the observations of selected traders ${ }^{3}$ in the area. Recent years have seen the loss of key traders such as supermarkets, an increase in the number of vacant premises and a deteriorating physical environment characterised by dilapidation and heavy traffic. The street continues, however, to serve its local community with a 


\section{Property deterioration}

\section{The Clifton Street study}

variety of shops and businesses and as such deserves attention from private sector investors and public bodies.

One of the problems voiced by traders has been deterioration in the appearance of shops and businesses, particularly of vacant units. The owners of these properties were held to blame for this situation, and some traders also said that their own landlords did little or nothing to maintain the premises in good condition. It seemed therefore that more intensive research into this issue would be useful.

The existing literature on inner-city retail and business problems has little to say on this topic. There appears to be no published research which has tried to identify ownership structures of such areas or to examine the roles and attitudes of property owners. The following case study is therefore exploratory in nature. In particular it is found that identifying property owners is itself a major problem. This means that it is difficult to draw up a representative sample of owners in order to investigate their attitudes and priorities. Nevertheless, the findings reported in this paper add to knowledge of the problems of inner-city business areas and the scope for improvement. They suggest that if suitable mechanisms are made available, both traders and landowners would be willing to participate in attempts to improve the economic health of such areas.

\section{BACKGROUND}

The research described in this paper continues a long-term study of Clifton Street begun in early 2002. The author was approached by the Cardiff office of the Scarman Trust, a charitable organisation which aims to mobilise community assets in inner urban areas. The Trust had already set up a community project in Adamsdown, the area which surrounds Clifton Street and which suffers social deprivation on several counts. The Trust had carried out consultations with local residents and businesses, which revealed considerable dissatisfaction with the state of Clifton Street, once a thriving shopping and business centre. It now wished to carry out a pilot study which would investigate further the problems of the area as a prelude to securing grant aid for further research, and lobbying Cardiff County Council and the Welsh Development Agency with regard to possible environmental improvements.

The main component of the pilot study was a survey of traders' and residents' attitudes towards Clifton Street, carried out in early 2002 by postgraduate students from Cardiff University. This established the nature of the problems facing Clifton Street and suggested ways in which both private and public sectors could act to halt the area's decline. ${ }^{4}$ Following the students' report and presentation to the traders' association in mid-2002, further presentations to local political representatives and the county council were made. These presentations received a sympathetic hearing but no promises of new expenditure. 


\section{Funding for research}

\section{What is the role of the property owners?}

The work achieved in the pilot study helped the Trust secure a small grant from the European Union's Objective Two and Transitional Programme 2000-2006, in order to carry out a feasibility study into ways of assisting social and economic development in Adamsdown, focusing particularly on the business areas of Clifton Street and Broadway. The grant was awarded on a basis of match funding by Cardiff University, which has taken the form of the author's unpaid participation in this project. The remainder of this paper describes research carried out as part of this study.

\section{RESEARCH OBJECTIVES}

One issue which was raised in the pilot study was the role of property owners. Some of the traders interviewed complained that owners were contributing to the decline of the area through lack of interest in their properties. The effects included long-term vacancies, and environmental deterioration through failure to maintain and repair properties. Resources available at that time did not allow any attempt to be made to follow up these complaints, however. The award of the Objective Two grant in mid-2003 made further investigation of this issue possible.

Any investigation of the role of property owners would need to establish first who they were. An obvious distinction exists between traders who own their premises and those who lease them from a landlord. The latter could take the form of a private individual owning a small number of commercial properties, or a specialist property company or a public body such as the local authority. It was also necessary to know landlords' identities in order to carry out questionnaire surveys of landlords themselves.

The second objective concerned the stereotype of the lazy, uncaring landlord - was this justified? This could be investigated through comparison of owner-occupied and leased properties, and through questioning of landlords.

The third objective was to find out how much landlords knew about the problems of the area, whether these perceptions were similar to those of traders and to what extent they were willing to engage in initiatives aimed at improving the area's environment and trading performance.

\section{RESEARCH METHODS}

Two surveys were carried out in order to investigate these questions. First, a survey of traders in Clifton Street was made, in order to establish as far as possible the identity of property owners, to collect views on the performance of landlords and to find out whether ownership structures had any effect on measures of business performance and confidence. The survey also included questions on business performance, future prospects and opinions about the area generally, which are not reported in detail in this paper. 


\section{Survey method}

\section{Who owns the premises?}

Secondly, a survey of landlords attempted to seek their views on the business performance and potential of Clifton Street, as well as their record of investment in the premises they owned.

Because the results of the traders' survey, in terms of establishing a database of landlord identities, turned out to be unsatisfactory (see below), a list of property owners was drawn up through use of the Land Registry (LR). So far as the author is aware, this method has not been attempted before in studies of urban renewal in the UK.

\section{TRADERS' SURVEY}

A survey questionnaire was devised by Cardiff University and agreed with Scarman Trust staff who discussed its format with one of the Clifton Street traders. The revised questionnaire was delivered by Cardiff University student volunteers to each of 75 retail and service businesses initially identified in Clifton Street. The students returned to collect the completed questionnaires after an interval of a few days: in some cases several repeat visits were needed. Eventually 46 completed questionnaires were recovered, a response rate of 61 per cent. This is a disappointing rate of response for a survey of this type, but not surprising given the level of despondency and apathy among traders observed in previous research. $^{5}$

Completed questionnaires were received from nine convenience retailers (mainly food shops), eight comparison (clothing, shoes etc), seven cafés and takeaways and 22 service businesses. The latter included hairdressers, travel and estate agents and financial and business services.

Traders were asked who owned the freehold of the premises concerned. Table 1 shows that 42 per cent of the respondents who answered this question stated that the business itself owned the freehold; this included the majority of food retailers. A similar proportion was owned by a private landlord based in the Cardiff area.

Those respondents who did not own their premises were asked 'how much interest your landlord shows in how your business is doing'. Answers tended towards either 'a lot' or 'none', with the owners of service premises generally showing more interest (Table 2).

Table I: Ownership of premises

\begin{tabular}{llllll}
\hline $\begin{array}{l}\text { Type of } \\
\text { business }\end{array}$ & $\begin{array}{l}\text { You/your } \\
\text { company } \\
\text { (as owner- } \\
\text { occupier) }\end{array}$ & $\begin{array}{l}\text { Private } \\
\text { landlord based } \\
\text { in the Cardiff } \\
\text { area }\end{array}$ & $\begin{array}{l}\text { A property } \\
\text { company or } \\
\text { financial } \\
\text { institution } \\
\text { based in the } \\
\text { Cardiff area }\end{array}$ & $\begin{array}{l}\text { A property } \\
\text { company or } \\
\text { financial } \\
\text { institution } \\
\text { based outside } \\
\text { the Cardiff area }\end{array}$ & $\begin{array}{l}\text { Other/don't } \\
\text { know }\end{array}$ \\
\hline Food retail & 6 & 3 & 0 & 0 & 0 \\
Non-food retail & 1 & 7 & 0 & 0 & 0 \\
Cafés, takeaways & 1 & 2 & 2 & 0 & 0 \\
Services & 9 & 6 & 1 & 1 & 1 \\
Total & 17 & 18 & 3 & 1 & 1 \\
\hline
\end{tabular}


Problems in using traders' information

\section{The Land Registry}

Table 2: Amount of interest of landlord in the business

\begin{tabular}{lllll}
\hline A lot & Some & Very little & None & Total \\
\hline 7 & 5 & 4 & 10 & 26 \\
\hline
\end{tabular}

In order to test the proposition that premises owned by a landlord might perform less well than those owned by the trader, answers to several questions were cross-tabulated against a simple variable which classified the premises as owner-occupied or tenanted. The greatest difference between the owner-occupiers and tenants was found in response to a question on business performance during the previous 12 months. Here, the owneroccupiers were more likely to have seen a deterioration in business level (eight out of 16 responses) than the tenants (four out of 23). There was little difference between the two categories in terms of perceived future prospects, or the perceived likelihood that the premises would be improved physically in the next three years. Given the small size of the survey sample, further reduced by nonresponse to various questions, further statistical analysis was not attempted.

\section{IDENTITY OF LANDLORDS}

It was intended initially to obtain a list of property owners in Clifton Street, large enough to be able to carry out a sample survey, from the results of the traders' survey. Following the question about the type of ownership (as shown in Table 1), each trader who was not an owner-occupier was asked to reveal the identity of their landlord. The information gained from the survey turned out to be inadequate, however. The question was ignored by several respondents, and in other cases a name was provided but no address. Only seven usable names and addresses of landlords were obtained from this part of the survey. In addition, there was no information about the owners of premises where traders had refused to take part in the survey, or of vacant premises in the area.

For these reasons LR information was used to try to establish ownership. For the sake of consistency it was decided to extend this search to all commercial premises on Clifton Street. ${ }^{6}$

The LR is an executive agency of the Secretary of State and Lord Chancellor which keeps records of all property transactions in the UK. The information it holds on many aspects of property ownership and other characteristics can be accessed by members of the public on payment of a small fee (currently $£ 2$ per property if accessed online at www.landregisteronline.gov.uk). This information includes the name and address of the registered owner(s) of the property concerned.

Use of the LR data turned out to be problematic for several reasons. Since the data are not collected for research purposes and depend upon unverifiable information drawn from a huge number 


\section{Problems in using LR data}

\section{Findings from LR data}

\section{Fragmentation of ownership}

of individual property transactions, one should not expect them to be fully comprehensive and reliable. ${ }^{7}$ Specific problems in this investigation included the following:

- for many properties both freehold and leasehold ownerships (sometimes more than one of these) were shown - here it was decided to investigate leasehold rather than freehold, on the grounds that lessees would probably have responsibility for repairs and insurance ${ }^{8}$

- 20 premises out of a total of 89 had no record at all at the LR this was probably because the land had been in the same ownership for many years and the event triggering its first registration, such as a sale or mortgage, had not occurred ${ }^{9}$

- in several cases the named owner of the premises could not be successfully contacted, presumably because the owner had moved address.

Out of 69 commercial or vacant premises in Clifton Street for which records existed (including some groups of adjacent buildings under single ownership), it was found that 18 were owned by a person, persons or company registered at the same address. This is similar to the total obtained from the trader survey, but a much lower proportion because that total was derived from a smaller sample. Presumably, some cases of owner-occupation noted from the trader survey extend back many years and therefore no transactions are recorded at the LR. It is also likely that some of the traders who stated that they owned the premises would be registered for LR purposes at their residential address.

A further 51 premises were owned by person(s) or a company at a different address, of which 43 lay within Cardiff and almost all of the remainder in areas close to Cardiff. The records suggest that a large majority of these property owners were private individuals as their addresses were residential in nature. It is also likely that several of these owners run the businesses in Clifton Street themselves, and should therefore be classed as owner-occupiers.

The general pattern revealed by the LR records and the traders' survey is of a very fragmented ownership structure. Around 40-45 per cent of premises appear to be owned by the person(s) trading at that address, although they may live elsewhere. The remaining 5560 per cent are owned by a large number of different persons or companies which are almost entirely based in Cardiff or the surrounding area. Most of these own only one property in Clifton Street; the maximum number owned by any person or company on the list was four. ${ }^{10}$ There is no ownership whatsoever by limited liability property companies or financial institutions, such as would be expected to own substantial parts of major high streets. ${ }^{11}$ The only public ownership recorded was of three adjacent properties owned by a housing association. 


\section{Survey method}

\section{Response rate}

\section{Expenditure by property owners}

\section{LANDLORD SURVEY}

These searches eventually produced 54 apparent property owners who had not already been surveyed in the guise of traders. The intention was now to survey all owners who were prepared to cooperate. The survey schedule included questions on the following:

- the use made of the properties owned, including upper floors

- how long, and why, any part of each property had remained vacant

- whether vacant upper floors could be let to residential tenants

- how much had been spent recently, and was likely to be spent in the near future, on repairs and refurbishment

- whether any public sector grants had been applied for in the last five years

- whether selling property in the area was seen as easy to do

- whether it was intended to buy further property in the area

- perceptions of the balance of shops and businesses in the area

- ideas on improving the area in general

- whether interested in discussing these issues with other landowners and/or participating in the work of the Adamsdown Community Forum

- any other comments.

Of the 54 possible respondents already identified, only 13 (24 per cent) eventually completed the questionnaire, either through personal interview, telephone interview or filling in a posted questionnaire. Thirteen more owners were successfully contacted but refused to participate, and the remaining 28 did not return telephone calls or posted questionnaires. Most of the latter lived at private residential addresses in the Cardiff area and some of their telephone numbers were ex-directory. In some cases it was made clear that the owner(s) no longer lived at that address, and therefore could not be contacted.

It should be emphasised that these attempts to contact and interview landlords took considerable time, effort and ingenuity, not to say persistence and a thick skin. Most interviews and some refusals were prefaced by several telephone calls. Some landlords took virulent exception to being identified and approached at all, not being aware that LR information is publicly available.

Because of the small number of responses to this survey, a detailed analysis is not attempted. A summary is shown in Table 3 . The table shows that, apart from one instance of major expenditure totalling around $£ 100,000$ over two adjacent properties, recently bought, little was being spent on repairs and refurbishment. Several respondents were interested in making further acquisitions in the area, but selling property was generally regarded as difficult. Encouragingly, there was a general willingness to communicate with other landlords and traders in the area in order to lobby the council and other agencies for investment and improvement. 
Table 3: Summary of landlord survey findings

Ownership

- The 13 respondents owned a total of 17 premises in Clifton Street.

- Periods of ownership ranged from less than one year (two responses) to over 45 years (two). Twelve of the premises had been owned for ten years or less.

- Twelve premises were in retail use. On upper floors, four were used for retail storage, two for offices, seven were residential and three vacant.

Vacant premises

- Only two reported vacant premises or parts thereof.

\section{Expenditure}

- The amount spent on repairs and refurbishment in the last year ranged from zero (five responses) to $£ 50,000$ (one response). Only two premises had had more than $£ 10,000$ spent on them.

- Intentions were to spend amounts from zero (three responses) to $£ 40,000-60,000$ (one) in the next 12 months. Only two premises were expected to attract more than $£ 5,000$ expenditure.

- None of the respondents had received any public sector grant to help pay for repairs or refurbishment in the last five years.

\section{Intentions}

- Of those who answered whether it 'would be easy to sell your property in this area within the next year or so', three said 'yes' (one because they would sell to the existing tenant), four said 'no', one had just sold the property and three were unsure.

- Three out of ten respondents who answered the question stated that they intended to buy further properties in the area 'within the next year or so'.

- Three out of ten said that they might be interested in both buying and selling in the Clifton Street area at the same time, and one was not sure.

General opinions and interest in the area

- Ten out of the 13 respondents felt that the 'balance of shops and businesses' in the area had deteriorated in the last five years; the other three said it had 'remained about the same'.

- Nine of the 13 did not routinely discuss these issues with other landlords or estate agents in the area.

- Six agreed that they 'would like to see some kind of discussion forum set up to discuss these issues', four were unsure and no one disagreed. The forum could take the form of regular meetings (four responses), a newsletter (seven) or an e-mail group (two). When asked 'who else could be involved', seven ticked 'traders/businesses', five ticked 'housing associations', seven 'county councillors' and four 'others' (one mentioned local residents under this heading)

- Finally, nine respondents said they would be 'interested in receiving more information about the Adamsdown Community Project'.

\section{Suggestions for improvements to the area}

Respondents also suggested many improvements which could be made to the balance of shops and businesses. These suggestions are compared with those raised in the traders' survey in Table 4.

It is clear that both groups see Clifton Street mainly as a

Table 4: Suggested improvements to the balance of shops and businesses in the area

\begin{tabular}{lll}
\hline Suggested improvements & $\begin{array}{l}\text { No. of suggestions from } \\
\text { traders' survey }(\mathbf{n}=\mathbf{4 6})\end{array}$ & $\begin{array}{l}\text { No. of suggestions from } \\
\text { landlords' survey (n = 13) }\end{array}$ \\
\hline Supermarket/frozen food store & 16 & 5 \\
Clothing shop & 15 & 1 \\
Small food shop & 11 & 5 \\
Small/local shops & 11 & 6 \\
Other retail (specific type) & 8 & 3 \\
Specifically greengrocer & 4 & 2 \\
Named multiple retailer & 4 & 8 \\
Chain store (unnamed) & 3 & 0 \\
Cafés etc & 3 & 2 \\
Banks, professional services & 2 & 8 \\
More shops generally & 1 & 3 \\
\hline
\end{tabular}


Table 5: Landlords' opinions on appropriate action to improve Clifton Street

\begin{tabular}{|c|c|c|c|}
\hline Landlords themselves & Traders & $\begin{array}{l}\text { Cardiff County } \\
\text { Council }\end{array}$ & Other agencies \\
\hline $\begin{array}{l}\text { Upgrade the exteriors of } \\
\text { buildings, maybe a uniform } \\
\text { colour }\end{array}$ & $\begin{array}{l}\text { Do not park outside } \\
\text { own shop all day }\end{array}$ & $\begin{array}{l}\text { More rubbish bins and } \\
\text { regular emptying }\end{array}$ & $\begin{array}{l}\text { Joint funding with landlords } \\
\text { (Housing associations) }\end{array}$ \\
\hline Improving appearance & Improving appearance & $\begin{array}{l}\text { Landscaping, } \\
\text { roadsweepers; give } \\
\text { grants to help } \\
\text { shopkeepers }\end{array}$ & $\begin{array}{l}\text { Grants and advice (Housing } \\
\text { associations) } \\
\text { Verbal support and lobbying } \\
\text { (Other) }\end{array}$ \\
\hline $\begin{array}{l}\text { General renovation - this } \\
\text { seems to be happening }\end{array}$ & Smarten up & $\begin{array}{l}\text { Looking at attracting } \\
\text { businesses }\end{array}$ & $\begin{array}{l}\text { Funding for exterior works } \\
\text { (Other) }\end{array}$ \\
\hline $\begin{array}{l}\text { Getting together, talking } \\
\text { about the future }\end{array}$ & $\begin{array}{l}\text { Involved more with local } \\
\text { community }\end{array}$ & $\begin{array}{l}\text { CCTV installed; low rates } \\
\text { as an incentive especially } \\
\text { for small traders; double } \\
\text { yellow lines to one side as } \\
\text { traffic problems and } \\
\text { parking are a major issue }\end{array}$ & \\
\hline $\begin{array}{l}\text { Meetings, helping residents' } \\
\text { associations }\end{array}$ & $\begin{array}{l}\text { Looking at getting } \\
\text { funding and investment }\end{array}$ & $\begin{array}{l}\text { Improved cleaning/refuse } \\
\text { collection; reduce rates } \\
\text { for small businesses }\end{array}$ & \\
\hline $\begin{array}{l}\text { Looking at getting funding } \\
\text { and investment }\end{array}$ & $\begin{array}{l}\text { Improvements to } \\
\text { properties }\end{array}$ & $\begin{array}{l}\text { Funding of investment, } \\
\text { developing the area }\end{array}$ & \\
\hline $\begin{array}{l}\text { Improvements to } \\
\text { properties }\end{array}$ & & Grants & \\
\hline Upgrading, needs grants & & $\begin{array}{l}\text { Looking at road safety } \\
\text { and rubbish }\end{array}$ & \\
\hline
\end{tabular}

\section{Are the suggestions realistic?}

traditional shopping street. The new businesses suggested in order to improve the area are very largely retail. Detailed comments suggest sympathy towards local residents and their needs. But these attitudes seem, in the opinion of Scarman Trust staff and the author, to be unrealistic. In the light of retail trends in Cardiff generally and elsewhere, Clifton Street has limited prospects as a retail centre, as the catchment population continues both to decline in numbers and to become more mobile.

The landlords differed to some extent from the traders in their suggestions. They were more likely to mention named multiple retailers, including Iceland, Tesco and Shaws (a locally based drapery retailer). They were also more likely to suggest banks and other business or professional services.

The landlords were asked what they, and other actors, should be doing in order to improve Clifton Street. The respondents' suggestions (in their own words) are shown in Table 5. Many of these suggestions recall the results of earlier surveys, ${ }^{12}$ particularly in the belief that the county council should both manage the public realm more effectively and provide funding for longer-term improvements. A realistic view emerges, however, on the responsibilities of both landlords and traders for improving the appearance of the area. 


\section{Ownership is fragmented and based locally}

\section{Variation in attitudes to the area}

\section{Does the future lie in diversification?}

In line with the landlords' and traders' opinions about the 'balance' of businesses, reported above, there is little enthusiasm shown here for a more radical restructuring of the area. For example, there is little acknowledgment of the potential role of housing associations or charities in either purchasing vacant properties or assisting in letting upper floors to residential tenants.

These suggestions were followed by a series of responses to a request for 'other comments'. These focused on two main issues: parking and traffic, and the shabby appearance of much of Clifton Street. These issues had already been raised in the feasibility study and in responses to the traders' survey.

\section{CONCLUSIONS}

This paper has examined patterns of property ownership in a typical non-central inner-city business area. The area is characterised by a long-term decline in business activity, and pessimistic attitudes among both traders and property owners. It appears that over half of the business premises are owned by landlords rather than the businesses themselves; and that property ownership is spread among a large number of individuals and small companies, almost all of them locally based. This bears the advantage that the property owners are generally familiar with the problems and potential of the area; but the fragmentation of ownership would make it difficult for any major redevelopment or reorganisation of land uses to take place. This problem is likely to be exacerbated by the unwillingness of some landlords to engage in discussions about the needs and prospects of the area.

The stereotype of the lazy, uncaring landlord is neither confirmed nor refuted in this investigation. Certainly some landlords appear to have no interest in their tenants' business, and some were very hostile to the survey itself. But others are clearly concerned to manage their property holdings efficiently and are worried about the decline which has affected the area in recent years. Among those landlords who cooperated with this survey, there exists a willingness to consider consolidating their property holdings, and to set up contacts with other landlords, traders and other local interests.

It is not clear, however, whether the area is going to improve simply through the expenditure and other activities of either traders or landowners. Neither is it sensible for everyone to sit back and wait for the county council to put improvements into effect. ${ }^{13}$ Clifton Street is only one of several inner-city and suburban business areas in Cardiff which have fallen into decline.

A more prosperous future may lie in diversification of land uses, involving, for example, cultural and community based activities, ${ }^{14}$ and in a planned shrinkage of the retail and service area with some replacement of business activity by residential use. Property owners will clearly have an important part to play in any such process, but the evidence suggests that the public sector will need to manage and 
perhaps coerce private property transactions in order to achieve long-term goals for this and other such areas.

\section{ACKNOWLEDGMENTS}

The research reported in this paper was funded by the European Union Objective Two Programme, and is managed by Terry Price of the Scarman Trust. Thanks are due to Patricia Smith and Angelique Chettiparamb for their valiant attempts in identifying property owners and carrying out surveys. The author is currently holder of an ESRC Research Fellowship award (ref. RES-000-270040).

\section{References and notes}

1. See for example Thomas, C. J. and Bromley, R. D. F. (1995) 'Retail decline and the opportunities for commercial revitalisation of small shopping centres: A case study in south Wales', Town Planning Review, Vol. 66, pp. 431-452; Whysall, P. (1995) 'Regenerating inner city shopping centres: The British experience', Journal of Retailing and Consumer Services, Vol. 4, pp. 45-61; Whysall, P. (2001) 'A shopping centre in decline: Hyson Green, 1973-1999', in Proceedings of the 11th International Conference on Research in the Distributive Trades, Tilburg, EIM Business and Policy Research, Zoetermeer, The Netherlands, Section C1.4; Collis, C., Berkeley, N. and Fletcher, D. R. (2000) 'Retail decline and policy responses in district shopping centres', Town Planning Review, Vol. 71, pp. 149-168; Bennison, D. and Jones, S. (2002) 'New strategies needed to reflect changing town centre activities', Urban Environment Today, 8 August, pp. 6-7.

2. Guy, C. and Duckett, M. (2003) 'Small retailers in an inner city community: A case study of Adamsdown, Cardiff', International Journal of Retail and Distribution Management, Vol. 31, pp. 401-407.

3. The term 'traders' is used to denote all retail and consumer service businesses operating in the area.

4. Guy and Duckett, ref. 2 above.

5. Ibid.

6. The area of search was defined as the 'Clifton Street' district shopping area in Cardiff County Council (2002) Retail Floorspace Survey 2001, Cardiff County Council, Cardiff; this includes a few premises in adjoining streets.

7. For more general discussion of property definitions and data in the UK, see Silman, G. (2002) 'The Land Registration Act 2002', Journal of Retail and Leisure Property, Vol. 3, pp. 190-198; Wyatt, P. (1999) 'The national land gazetteer: Addressing property properly?', Journal of Property Investment and Finance, Vol. 17, pp. 191-205.

8. Registered leases have to be at least 21 years in duration.

9. Land Registry (2003) 'A guide to the information we keep and how you can obtain it', Land Registry Public Guide No. 1, Land Registry, London, p. 4.

10. This company (as revealed in the landlords' survey) owned four groups of properties eight premises in all.

11. Guy, C. M. (1994) The Retail Development Process, Routledge, London, pp. 103-107.

12. Guy and Duckett, ref. 2 above.

13. Since this paper was written, Cardiff County Council have secured funding from the Welsh Assembly Government's Physical Regeneration Fund, to develop a regeneration strategy for the area.

14. See for example Hart, A. (2003) 'A neighbourhood renewal project in Dalston, Hackney: Towards a new form of partnership for inner-city regeneration', Journal of Retail and Leisure Property, Vol. 3, pp. 237-245. 